\title{
PERAN BADAN USAHA MILIK DESA DALAM MEMBERDAYAKAN MASYARAKAT DESA LIBERIA KECAMATAN TELUK MENGKUDU KABUPATEN SERDANG BEDAGAI
}

\author{
Halimatus Sakdiah, Iqbal Muin, Husni Ritonga \\ Program Studi Pengembangan Masyarakat Islam, Fakultas Dakwah dan \\ Komunikasi, Universitas Islam Negeri Sumatera Utara
}

\begin{abstract}
Abstrak: Penelitian ini bertujuan untuk mengungkapkan peran badan usaha milik desa dalam memberdayakan masyarakat desa. Penelitian ini dilaksanakan di Desa Liberia Kecamatan Teluk Mengkudu Kabupaten Serdang Bedagai. Metode yang digunakan dalam penelitian ini adalah kualitatif pendekatan deskriptif. Sumber data yang digunakan adalah data primer dan skunder. Data diproleh dengan cara observasi, wawancara dan dokumentasi Temuan penelitian ini sebagai berikut : (1) peran badan usaha milik desa dalam memberdayakan masyarakat desa memberikan bantuan maupun permodalan usaha serta memberikan kemudahan dalam membayar pinjaman dari BUMDESA dengan menyicil setiap bulan nya dalam tempo satu tahun, masyarakat tersebut sudah terdaftar dalam kegiatan BUMDESA.(2) Perkembangan perekonomian badan usaha milik desa pada awalnya masyarakat desa Liberia tidak mengetahui keberadaan BUMDESA bahwa dapat membantu dalam memajukan usaha yang mereka jalani agar lebih berkembang dalam meningkatkan perekonomian usaha masyarakat desa. (3) faktor penghambat dan pendukung BUMDESA, faktor penghambatnya dikarena kurangnya bantuan dana dari pemerintah dan kurangnya fartisifasi masyarakat dalam mengelola potensi desa serta memahami maksud keberadaan BUMDESA didesa Liberia. Sedangkan faktor pendukungnya, yaitu BUMDESA menjadi bantuan dana desa satu-satunya yang langsung memberikan dana pinjaman kepada masyarakat guna untuk meningkatkan dan menumbuhkan perekonomian usaha masyarakat agar terus maju dalam memanfaatkan permodalan yang telah digerak oleh BUMDESA.
\end{abstract}

Kata Kunci: Peran, Pemberdayaan, Masyarakat Desa, BUMDes

\section{PENDAHULAN}

Desa merupakan wilayah terkecil dari Negara Indonesia yang terdekat dengan masyarakat dan memiliki batas wilayah agar dapat disejahterakan maupun diberdayakan. Desa memiliki banyak potensi tidak hanya dari segi jumlah penduduk, tetapi juga ketersediaan sumber daya alam yang melimpah. 
Jika kedua potensi ini bisa dikelola dengan maksimal maka akan memberikan kesejahteraan bagi penduduk desa. ${ }^{1}$ Akan tetapi, disadari bahwa selama ini pembangunan pada tingkat desa masih memiliki banyak kelemahan. Kelemahan pembangunan pada tingkat desa antara lain disebabkan tidak hanya karena persoalan sumber daya manusia yang kurang berkualitas tetapi juga disebabkan karena persoalan keuangan.

Umat Islam mempunyai Alquran dan Hadist, Nabi sebagai pedoman hidup dalam kehidupan bermasyarakat, Alquran memerintahkan kepada umat manusia khususnya umat Islam, untuk melaksanakan pembangunan, dan perubahan hidup baik dalam kehidupan material dan maupun kehidupan spiritual.

Allah Swt memerintahkan kepada umatnya untuk selalu berusaha dalam memenuhi kebutuhan hidupnya, ${ }^{2}$ sebagaimana Firman Allah Swt dalam Surah ArRa'd ayat 11 : "Bagi manusia ada malaikat-malaikat yang selalu mengikutinya bergiliran, dimuka dan dibelakangnya, mereka menjaganya atas perintah Allah. Sesungguhnya Allah tidak merubah keadaan sesuatu kaum sehingga mereka merubah keadaan yang ada pada diri mereka sendiri. Dan apabila Allah menghendaki keburukan terhadap sesuatu kaum, maka tak ada yang dapat menolaknya, dan sekali-kali tak ada pelindung bagi mereka selain Dia” (Q.s. ArRa'ad:11).

Ayat ini menerangkan tentang kedzaliman manusia. Dalam ayat ini juga dijelaskan bahwa kebangkitan dan keruntuhan suatu bangsa tergantung pada sikap dan tingkah laku mereka sendiri. Kedzaliman dalam ayat ini sebagai tanda rusaknya suatu kemakmuran bangsa. Adapun penjelasan tafsir Dafertemen Agama ayat ini ialah Allah Swt Menugaskan kepada beberapa malaikat untuk selalu mengikuti manusia secara bergiliran, di muka dan di belakangnya, mereka menjaganya atas perintah Allah. Ada malaikat yang menjaganya dimalam hari dan ada yang di siang hari, menjaga dari berbagai bahaya dan kemudaratan, dan ada pula malaikat yang mencatat semua amal perbuatan manusia, yang baik atau yang buruk. Dua malaikat di sebelah kanan dan di sebelah kiri yang mencatat amal perbuatan manusia yang baik atau yang buruk.

\footnotetext{
${ }^{1}$ Boediono, Teori Pertumbuhan Ekonomi (Yogyakarta: BPFE, 1993), h.5.

${ }^{2}$ Dafertemen Agama RI, Al-qur'an dan terjemahannya, (Bandung: CV Penerbit Jumantul Ali-Art,2004), h. 250
} 
Apabila manusia mengetahui bahwa di sampingnya ada malaikat-malaikat yang mencatat semua amal perbuatannya, maka patutlah ia menjaga diri dari perbuatan maksiat karena khwatir akan dilihat oleh malaikat-malaikat itu seperti kekhawatirannya perbuatan itu di lihat oleh oramg-orang yang di segani. Dan apabila Allah menghendaki keburukan kepada suatu kaum dengan penyakit kemiskinan atau bermacam-macam cobaan yang lain sebagai akibat dari perbuatan buruk yang mereka kerjakan sendiri, maka tak ada seorang pun yang dapat menolaknya dan sekali-kali tak ada pelindung bagi mereka selain Allah Ta'ala sendiri. ${ }^{3}$

Adapun dikatakan Desa Liberia berawal dari direnofasinya gedung tua yang dulunya dibangun oleh Rubber Cultuur Maatschappij Amsterdam (RCMA) pada tahun 1916 yang berlokasi ditepi jalan lintas sumatera kilometer KM 50-54, masuk wilayah Desa Liberia Kecamatan Teluk Mengkudu Kabupaten Serdang Bedagai. Melalui nasionalisasi perkebunan milik belanda, maka sejak tahun 1958 menjadi perusahaan perkebunan negara dan terakhir menjadi PTPN.3. diketahui perkebunan itu dulunya milik seorang jerman bernama Blunschli dengan tanaman tembakau dan belakangan diganti menjadi kopi yang bibitnya dibawa dari Liberia, Afrika. Oleh karena itu disebutlah desa itu menjadi Desa Liberia.

Untuk menghidupkan perekonomian desa perlu didirikan lembaga yang merangkul seluruh potensi dan kearifan lokal desa. Lembaga dimana merupakan wadah setiap warga desa memberikan kerja keras, buah pikiran, segenap potensi diri dan saling berbagi peran. Lembaga yang sesuai bagi masyarakat desa yang menghilangkan penindasan antar masyarakat desa adalah Badan Usaha Milik Desa (BUMDESA). ${ }^{4}$

Berhasil atau gagalnya suatu badan pembangunan masyarakat desa akan dipengaruhi oleh sikap masyarakat terhadapnya. Menghadapi situasi semacam ini badan-badan pembangunan masyarakat desa membentuk masyarakat dan bukan membangun masyarakat, namun kebanyaan dari mereka mencoba mengerjakannya dengan menarik orang-orang kedalam kelompok-kelompok. ${ }^{5}$

\footnotetext{
${ }^{3} \mathrm{I} b i d$, h. 250

${ }^{4}$ Ibid, h. 5

${ }^{5}$ Surjadi, Pembangunan Masyarakat Desa,(Bandung : Mandar Maju, 1989), h. 80
} 
Berbagai upaya telah dilakukan pemerintah dengan menggelontarkan berbagai dana untuk program pembangunan desa yang salah satunya adalah melalui Badan Usaha Milik Desa (BUMDESA). Menurut peraturan menteri dalam negeri nomor 39 tahun 2010, BUMDESA merupakan usaha desa yang dibentuk/didirikan oleh pemerintah desa dimana kepemilikan modal dan pengelolaannya dilaksanakan oleh pemerintah desa dan masyarakat.

Tujuan dari dibentuknya BUMDESA merupakan upaya pemerintah untuk meningkatkan kemampuan keuangan pemerintah desa dalam penyelenggaraan pemerintahan dan meningkatkan pendapatan masyarakat melalui berbagai kegiatan usaha ekonomi masyarakat perdesaan, dengan berdirinya BUMDESA.

Selanjutnya pemerintah juga diharapkan dapat menciptakan iklim usaha yang mendorong perkembangan perekonomian secara sehat, baik dalam meningkatkan kesejahteraan anggota dan masyarakat sekitarnya, maupun turut serta dalam membangun sistem perekonomian nasional sebagian organisasi ekonomi, perkembangan Badan Usaha Milik Desa (BUMDESA) tidak mungkin dapat dilepaskan dari kondisi persaingan yang dihadapinya dengan pelaku-pelaku ekonomi yang lain.

Sumber pendapatan desa merupakan salah satu intsrumen untuk meningkatkan perekonomian desa. Pertumbuhan ekonomi desa seringkali dinilai lambat dibandingkan pembangunan ekonomi perkotaan. Untuk meningkatkan hal tersebut dibutuhkan dua pendekatan yaitu: kebutuhan masyarakat dalam melakukan upaya perubahan dan mencegah hal-hal yang tidak diinginkan dan Political will kemampuan pemerintah desa bersama masyarakat dalam mengimplementasikan perencanaan pembangunan yang sudah disusun oleh Badan Usaha Milik Desa (BUMDESA) melalui kegiatan simpan pinjam. ${ }^{6}$

Salah satu upaya yang bisa dilakukan adalah dengan mendorong gerak ekonomi desa melalui kewirausahaan desa, dimana kewirausahaan desa menjadi strategi dalam mengembangan dan pemberdayaan desa. Sumber pendapatkan desa tersebut merupakan sumber pendapatan desa yang diterima dari usaha-usaha yang dilakukan oleh pemerintah desa bersama dengan Badan Permusyawaratan Desa (BPD) dan masyarakat desa. Selama ini sumber-sumber pendapatan desa yang ada

${ }^{6}$ Ibid, h. 80 
belum bisa dimaksimalkan untuk meningkatkan pendapatan desa, terutama karena pemerintah desa hanya mengedalikan bantuan dana dari pemerintahan di atasnya.

BUMDESA diatur dalam UU No. 32 tahun 2004 tentang otonomi daerah dalam pasal 213 ayat 1, tentang pemerintahan desa. Pasal tersebut menyebutkan bahwa "desa dapat mendirikan badan usaha milik desa sesuai dengan kebutuhan dan potensi desa". Disebutkan juga bahwa tujuan utama berdirinya badan usaha tersebut adalah untuk meningkatkan pendapatan asli desa dan untuk meningkatkan kesejahteraan masyarakat desa. ${ }^{7}$

Berikut ini adalah empat tujuan utama dari pendirian BUMDESA Adalah :

1. Meningkatkan perekonomian desa

2. Meningkatkan pendapatan asli desa

3. Meningkatkan pengolahan asli potensi desa

4. Menjadi tulang punggung pertumbuhan dan pemerataan ekonomi desa

Pengertian tentang pendirian badan usaha yang sesuai dengan kebutuhan dan potensi daerah mengandung arti bahwa pendirian BUMDESA harus berdasarkan pada kebutuhan dan potensi lokal desa, dalam rangka pembangunan kesejahteraan masyarakat ${ }^{8}$. Sebenarnya pengembangan basis ekonomi desa sudah semenjak lama di jalankan oleh pemerintahan melalui berbagai program dan kegiatan, tetapi selalu saja kurang memuaskan, terdapat banyak faktor yang menjadi penyebab kurang berhasilnya program pemerintah.

Salah satu faktor yang paling dominan adalah terlalu besarnya intervensi pemerintahan terhadap desa, yang pada akhirnya malah mempersulitkan daya kreatifitas dan inovasi masyarakat desa dalam menjalankan perekonomiannya. Akibat sistem dan mekanisme kelembagaan ekonomi diperdesaan berjalan lambat dan tidak efektif sehingga menimbulkan efek ketergantungan pada bantuan pemerintahan yang kurang jiwa kemendirian. Terlebih dulu dari yang masa sebelumnya, dimana banyak program-program pemerintahan yang terbukti gagal dalam meningkatkan kesejahteraan masyarakat perdesaan.

\footnotetext{
${ }^{7}$ Tim Visi Yustisida, Pedoman Resmi Petunjuk Pelaksanaan Dana Desa, (Jakarta: PT. Visimedia Pustaka (Anggota IKAPI), 2016), h. 22

${ }^{8}$ Chamber, Robert. Pembangunan Desa, (Jakarta: LP3ES, 1987), h.53
} 
Pemerintah menjadikan BUMDESA sebagai salah satu program andalan dalam meningkatkan kemendirian perekonomian desa. Dalam hal sini unit usaha simpan pinjam bertujuan untuk kebaikan demi kesejahteraan orang lain. Pendiri dan Pengerak serta anggota BUMDESA di Desa Liberia secara keseluruhan masyarakat islam dan BUMDESA di desa ini telah banyak membantu masyarakat pedagang kecil dalam meningkatkan perekonomiannya melalui simpan pinjam yang digerakkan oleh BUMDESA dengan persenan yang cukup kecil, sesuai dengan pendapatan usaha masyarakat tersebut dan dapat dicicil setiap bulan dalam satu tahun, hal ini berbeda dengan bantuan dana lainnya seperti bantuan dari kelompok PKK, Koperasi dan kelompok organisasi lainnya.

Alasan lainnya, karena ada banyak kasus lembaga simpan pinjam yang gulung tikar dikarenakan banyaknya peminjam yang tidak mengembalikan hutangnya, sehingga banyak perangkat desa yang khawatir jika membuat simpan pinjam uangnya tidak kembali seperti nasib buruk lembaga simpan pinjam lainnya.

Selanjutnya, alasan yang lain mengenai simpan pinjam ini sudah umum dibuat sehingga tidak akan menciptakan kesan inovatif kala dana desa atau BUMDESA membuka lembaga keuangan serupa. Padahal sesungguhnya, lembaga keuangan simpan pinjam adalah salah satu jenis usaha yang justru paling mampu menciptakan multi efek bagi ekonomi desa.

Sebagai lembaga yang mampu mendukung sistem permodalan para pelaku ekonomi desa, perbankan desa bisa mendukung segala jenis usaha masyarakat. Di desa manapun diwilayah manapun permodalan adalah salah satu mesin penggerak perekonomian. ${ }^{9}$ Namun meskipun banyaknya permodalan yang telah ada di tengah-tengah masyarakat dan membantu para warga desa, BUMDESA memiliki peran yang sangat fundemental dalam memacu produktivitas ekonomi warga dan meningkatkan ekonomi desa melalui simpan-pinjam tersebut, dan masyarakat desa tetap melakukan simpan pinjam yang telah di gerakkan oleh BUMDESA.

Selanjutnya, perkembangan desa yang berbasis masyarakat ini bisa terus menjadi perkembangan berkelanjutan tentunya memerlukan pemberdayaan kepada masyarakat untuk ikut serta dalam mengelola Badan Usaha Milik Desa

\footnotetext{
${ }^{9}$ Ibid., h. 153
} 
(BUMDESA) yang pada saat ini kegiatan desa yang berjalan melalui simpan pinjam. Oleh karena itu peneliti tertarik untuk melakukan Penelitian tentang permasalahan di Desa Liberia Kecamatan Teluk Mengkudu Kabupaten Serdang Bedagai dalam mengelola badan usaha milik desa yang dilaksanakan oleh pendamping atau pengerak masyarakat desa melalui kegiatan simpan pinjam yang berjalan pada saat ini.

\section{METODE PENELITIAN}

Penelitian ini di lakukan di Desa Liberia Kecamatan Teluk Mengkudu Kabupaten Serdang Bedagai. Pemilihan lokasi penelitian ini ditentukan secara Purposive yaitu didasarkan pada pertimbangan bahwa di Desa Liberia merupakan desa yang telah melaksanakan pemberdayaan melalui peran BUMDESA. Dengan demikian maka penulis tertarik untuk meneliti peran BUMDESA dalam Pemberdayaan Khususnya di Desa Liberia Kecamatan Teluk Mengkudu Kabupaten Serdang Bedagai.

Penelitian ini merupakan penelitian deskriptif dengan menggunakan pendekatan kualitatif, yang bertujuan untuk menggungkap fakta, keadaan, fenomena dan keadaan yang terjadi saat penelitian berjalan, dan mengambarkan profil Desa Liberia serta kelompok simpan pinjam yang telah digerakkan oleh BUMDESA tersebut. ${ }^{10}$ Menurut Denzin dan Licoln yang dikutip dari buku Juliansyah Noor, penelitian kualitatif adalah kata kualitatif menyiratkan penekanan pada proses dan makna yang tidak dikaji secara ketat atau frekuensinya. ${ }^{11}$ Jadi pendekatan penelitian kualitatif adalah suatu proses penelitian dan pemahaman berdasarkan metode yang melalui suatu penomena sosial dan masalah manusia. Pada pendekatan ini penelitian menekankan sifat realitas yang terbangun secara sosial, hubungan erat antara peneliti dan subjek yang diteliti.

Teknik data primer data yang diperoleh dari pengurus BUMDESA dan aparatur desa yang menjalankan pelayanan simpan pinjam dan meningkatkan perekonomian masyarakat di Desa Liberia Kecamatan Teluk Mengkudu Kabupaten Serdang Bedagai. Sumber data ini merupakan data yang diperoleh dari

\footnotetext{
${ }^{10}$ Winarno Surakhmad, Pengantar Penelitian Ilmiah, (Bandung: Tarsino, 1982), h. 141

${ }^{11}$ Juliansyah Noor, Metodelogi Penelitian, (Jakarta: Kencana Prenadamedia Group, 2011) ,h. 33
} 
narasumber secara langsung baik melalui wawancara, kuisioner, ataupun dengan melakukan pengamatan langsung kelapangan. Adapun pertanyaan yang diajukan dalam penelitian ini meliputi data seperti peran Badan Usaha Milik Desa (BUMDESA) dalam memberdayakan masyarakat desa dan faktor yang menjadi dan penghambat dan pendukung dari berjalannya simpan pinjam yang sebagaimana dikelola oleh BUMDESA.

Sedangkan tehnik data skunder dari penelitian ini sebagai data yang diperoleh dari buku-buku, media cetak dan internet serta, peraturan-peraturan yang tertulis atau dokumen yang berhubungan dengan masalah yang diteliti.

Instrumen utama pengumpulan data pada sebuah penelitian kualitatif adalah peneliti itu sendiri, sebagaimana disebutkan Garna, bahwa "Instrumen penelitian adalah manusia itu sendiri, artinya peneliti perlu sepenuhnya memahami dan adaptif terhadap situasi sosial dalam kegiatan penelitian itu".Berhubungan instrumen penelitian kualitatif adalah peneliti itu sendiri, maka dalam penelitian ini, peneliti terjun kelapangan dengan membawa alat bantu yang diperlukan antara lain : pedoman wawancara, catatan lapangan, alat perekam, serta kamera.

Untuk memperoleh data yang diperlukan, maka dipergunakan teknik sebagai berikut :

\section{Wawancara (Interview)}

Teknik wawancara dalam penelitian ini menggunakan serangkaian pertanyaan kepada sejumlah responden yang mampu memberikan keterangan yang diperlukan oleh penulis yaitu peran badan usaha milik desa serta masyarakat yang melakukan simpan pinjam. Dalam rangka pengumpulan data, peneliti melalukan wawancara terstruktur maupun tidak terstruktur untuk mendapatkan keterangan-keterangan atau pendirian secara lisan dari seorang informan lain yang menilai peran Badan Usaha Milik Desa (BUMDESA).

Metode wawancara digunakan untuk mengumpulkan data primer yaitu memperoleh data atau informasi secara langsung untuk proses pengolahan selanjutnya. Menurut Nazir adalah proses memperoleh keterangan untuk tujuan 
penelitian dengan cara tanya jawab sambil bertatap muka antara si penanya dan pewawancara dengan si penjawab atau responden dengan menggunakan alat yang dinamakan interview guide (panduan wawancara). ${ }^{12}$

\section{Pengamatan (Observasi)}

Mengadakan pengamatan langsung dilapangan untuk mendapatkan gambaran secara nyata tentang masalah yang diteliti untuk mengetahui kondisi yang sebenarnya.

Menurut Burhan Bungin mengemukakan beberapa bentuk observasi yang dapat digunakan dalam penelitian kualitatif, yaitu observasi partisifasi, observasi tidak terstruktur dan observasi kelompok tidak terstruktur. ${ }^{13}$ Observasi partisifasi (participant observasion) adalah metode pengumpulan data yang digunakan untuk menghimpun data penelitian melalui pengamatan dan pengindraan dimana observasi atau peneliti benar-benar terlibat dalam keseharian responden. Observasi tidak berstruktur adalah observasi yang dilakukan tanpa menggunakan guide observasi. Pada observasi ini peneliti atau pengamat harus mampu mengembangkan daya pengamatannya dalam mengambil suatu objek. Sedangkan observasi kelompok tidak tersetruktur adalah observasi yang dilakukan secara berkelompok terhadapat sesuatu objek sekaligus.

3. Dokumentasi

Tehnik dokumentasi dalam penelitian ini digunakan sebagai data pendukung

dari teknik wawancara dan observasi, dan untuk mendapatkan kumpulan data yang serupa seperti foto-foto pengurusan BUMDESA dan masyarakat setempat. Menurut Sugiyono, studi dokumen merupakan pelengkap dari penggunaan metode observasi dan wawancara dalam penelitian kualitatif. Bahkan kredibilitas hasil penelitian kulitatif ini akan semakin tinggi jika melibatkan atau menggunakan studi dokumen ini dalam metode penelitian kualitatif. ${ }^{14}$

Menurut Sugiono Subjek penelitian merupakan tempat variabel melekat, subjek penelitian sebagai tempat dimana data untuk variabel penelitian di

\footnotetext{
${ }^{12}$ Ibid,.h. 34

${ }^{13}$ Burhan Bungin, Metodologi Penelitian Kualitiatif, (Jakarta:Raja Wali Pres, 2011),

${ }^{14}$ Sugiono, Metode Penelitian Kuantitatif dan Kualitatif, (Bandung; Alfabeta, 2008), h. 4
} h. 144 
peroleh. ${ }^{15}$ Adapun dalam penelitian ini yang menjadi Subjek penelitiannya adalah simpan pinjam yang digerakkan oleh BUMDESA serta perkembangan perekonomian masyarakat yang ada didesa tersebut.

Informan dalam penelitian ini ada sebanyak 5 orang yang di ambil diantaranya kepala desa dan pengurus BUMDESA serta masyarakat di desa yang melakukan simpan pinjam di Desa Liberia Kecamatan Teluk Mengkudu Kabupaten Serdang Bedagai. Alasan pemilihan informan sebagai sumber data dalam penelitian ini adalah berdasarkan pada asas objek yang menguasai permasalahan, memiliki data, dan bersedia memberikan informan lengkap dan akurat, serta dapat menentukan informan kunci dengan tehnik snowball sampling, yaitu berdasarkan informan sebelumnya tanpa menentukan jumlahnya secara pasti dengan mengali informasi terkait topik penelitian yang diperlukan. Pencarian informan akan diberhentikan setelah informasi penelitian di anggap sudah memadai.

Informan yang dikemukakan oleh Moleong adalah "orang yang dimanfaatkan untuk memberikan informasi tentang situasi dan kondisi latar belakang penelitian". ${ }^{16}$ Adapun yang menjadi informan dari penelitian ini adalah :

1. Nama : Dirga Wira Setia SH, SPd

Usia : 40 Tahun

Pekerjaan/Jabatan : Ketua BUMDESA

Alamat : : Desa Liberia Kecamatan Teluk Mengkudu

2. Nama : Ade Septia Ningsih

Usia $\quad: 38$

Pekerjaan/Jabatan : Sekretaris BUMDESA

Alamat : Desa Liberia Kecamatan Teluk Mengkudu

3. Nama : Evi Herawati

Usia : 43 Tahun

Pekerjaan/Jabatan : Bendahara BUMDESA

Alamat : Desa Leberia Kecamatan Teluk Mengkudu

4. Nama : Iryansyah Putra

Usia : 39 Tahun

${ }^{15} \mathrm{Ibid}, \mathrm{h}$ h 95

${ }^{16}$ Ibid., h. 95 
Pekerjaan/Jabatan: Kepala Desa Liberia

Alamat : Desa Liberia, Kecamatan Teluk Mengkudu

5. Nama : Nurhasanah

Usia : 42 Tahun

Pekerjaan/jabatan : Pedagang Kecil \& Anggota Peminjam BUMDESA

Alamat : Desa Liberia, Kecamatan Teluk Mengkudu

Sesuai karateristik penelitian kualitatif dalam bentuk studi kasus, maka analisis data dilakukan sepanjang proses berlangsungnya penelitian. Data yang berhasil di kumpulkan diklarifikasikan kemudian bergerak ke arah pembentukan kesimpulan. Proses analisis data didasarkan pada penyederhanaan dan interpretasi data yang dilaksanakan sebelum, selama dan sesudah proses pengumpulan data. Proses ini terdiri dari tiga sub proses yang saling berkaitan yaitu data reduction, data display, dan conclusion drawing/verification.

Menurut Miles dan Huberman yang dikutip oleh Ulber berdasarkan pada pendapat diatas, maka transkrip interview serta hasil-hasil observasi yang telah terkumpul dilakukan tahapan analisis sebagai berikut: ${ }^{17}$

1. Reduksi data/data reducation, yaitu proses pemilihan, pengklarifikasian, pengabstraksian atau transparansi data yang diperoleh dilapangan baik melalui observasi maupun wawancara kepada informan pangkal dan informan kunci. Reduksi data merupakan bentuk analisis menanjamkan, menggologkan, mengarahkan, membuang yang tidak perlu, dan mengorganisasian data sehingga kesimpulan dapat ditarik dan diferifikasi.

2. Penyajian data/data display, yaitu sekumpulan informasi dan data yang memberi kemungkinan adanya penarikan kesimpulan dan mengambil tindakan. Penyajian tersebut bisa dalam bentuk uraian, grafik, dan bagan.

3. Penarikan kesimpulan/conclusion, yaitu penganalisaan akhir yang diperoleh berdasarkan hasil reduksi data dan penyajian data.

Menurut Creswell menyatakan penelitian kualitatif sebagai suatu gambaran kompleks, meneliti kata-kata, laporan terinci dari pandangan responden, dan melakukan studi pada situasi yang alami. ${ }^{18}$ Penelitian ini dilakukan disatu desa yang terletak di Desa Liberia Kabupaten Serdang Bedagai. Penelitian yang

${ }^{17}$ Ulber Silalahi, Metode Penelitian Sosial, (Bandung: PT Refika Aditama, 2009), h. 339

${ }^{18}$ Ibid., h. 34 
dilakukan mampu menggali penomena dinamika ekonomi dan badan usaha milik desa atau BUMDESA di desa tersebut.

\section{HASIL DAN PEMBAHASAN}

\section{Program BUMDESA Dalam Pemberdayaan Masyarakat Desa di Desa}

\section{Liberia}

Banyak kebijakan pemerintah yang berionterasi pada masyarakat kecil yang bertujuan untuk meningkatkan kesejahteraan dan memberdayakan masyarakat. Oleh karena itu pemerintah membuat kebijakan berbentuk lembaga ekonomi ditingkat perdesaan. Lembaga ekonomi ditingkat perdesaan menjadi bagian yang sangat penting dalam rangka untuk mendukung pemberdayaan dan penguatan ekonomi kerakyatan sehingga dapat mensejahterakan masyarakat. Dilihat dari beberapa indikator kesejahteraan masyarakat desa Liberia menunjukkan bahwa kebanyakan dari masyarakat yang ada didesa Liberia masuk dalam kategori keluarga sejahtera, yaitu keluarganya sudah dapat memenuhi kebutuhan dasar minimalnya seperti kebutuhan sandang, pangan, papan dan kesehatan juga kebutuhan seperti pendidikan dan interaksi dengan keluarga serta lingkungan tempat tinggal. ${ }^{19}$

Oleh karena itu program badan usaha milik desa (BUMDESA) telah membantu meningkatkan kualitas masyarakat dan memberdayakan masyarakat dengan adanya faktor lain. Program dari BUMDESA bisa memaksimalkan di bidang unit usaha simpan pinjam untuk masyarakat desa Liberia. ${ }^{20}$ BUMDESA belum dapat dikatakan berkembang tapi Pembina BUMDESA Bapak Iryansyah Putra selaku kepala desa yang menjadi pembina dari BUMDESA menyatakan kelompok pembina ini memiliki keyakinan untuk perkembangan yang lebih positif kedepannya dengan kepengurusan yang lebih baik lagi dan juga unit-unit usaha baru yang akan dikembangkan seperti lembaga micro finance atau lembaga keuangan mikro yang akan membantu masyarakat untuk membuka peluang usaha

${ }^{19}$ Wawancara Kepada Bapak Iryansyah Putra, Kepala Desa Liberia Dan Pembina BUMDESA, Kantor Desa, Desa Liberia Kecamatan Teluk Mengkudu Kabupaten Serdang Bedagai, Jam 10.20 Wib, Tanggal 12 April 2018.

${ }^{20}$ Ibid, Jam 10.20 Wib , Tanggal 12 April 2018 
ataupun mengembangkan usaha yang salah satu dimiliki oleh masyarakat desa Liberia. $^{21}$

Dari uraian diatas tentang kebutuhan dasar dalam islam pula bahwa dari segi kebutuhan primer, sekunder dan kebutuhan pelengkap bahwa BUMDESA sudah berperan dalam memberdayakan masyarakat menurut pandangan islam seperti pada kebutuhan primer dari segi harta. ${ }^{22}$

BUMDESA sudah membantu masyarakat untuk memproleh harta dengan cara yang halal, kemudian untuk kebutuhan sekunder masyarakat BUMDESA telah berperan dalam memudahkan kesulitan yang dialami masyarakat yaitu dengan adanya unit usaha simpan pinjam. ${ }^{23}$

Dalam hal menjalankan pekerjaan atau menggunakan jasa dari unit-unit usaha yang dikelola BUMDESA ini dengan tetap mengikuti syariat-syariat islam. Didesa Liberia kecamatan teluk mengkudu kabupaten serdang bedagai ini memberikan program unit usaha simpan pinjam kepada masyarakat desa Liberia yang berada pada tiga dusun, yang tiap-tiap dusun tersebut membuat kelompok simpan pinjam yang diarahkan oleh Pembina BUMDESA dan aparat desa, mereka mengarahkan kepada masyarakat desa untuk memanfaatkan pinjaman yang diberikan oleh BUMDESA dengan sebaik mungkin, dan dapat berkembang sesuai dengan keinginan. Dengan adanya BUMDESA ini dapat membentuk masyakat dengan tatanan sosial yang solid berdasarkan sistem ekonomi syariah yang digerakkan oleh BUMDESA dengan unit usaha simpan pinjam selain itu menimbulkan persaudaraan yang universal sehingga antar dusun tersebut dapat menyadari dengan tugasnya dan aturan-aturan yang telah ditetapkan oleh pihak BUMDESA. $^{24}$

1. Pendapatan

Pendapatkan yang diperoleh masyarakat yang berasal dari pendapatan kepala rumah tangga maupun pendapatan anggota-anggota rumah tangga. Penghasilan tersebut biasanya di alokasikan untuk konsumsi, kesehatan, maupun pendidikan dan kebutuhan lain yang bersifat material. ${ }^{25}$

\footnotetext{
${ }^{21}$ Ibid, Jam 10.20, Tanggal 12 April 2018

${ }^{22}$ Ibid, Jam 10 20, Tanggal 12 April 2018

${ }^{23}$ Ibid, Jam 10.20 , Tanggal 12 April 2018

${ }^{24}$ Ibid, Jam 10.30, Tanggal 12 April 2018

${ }^{25}$ Ibid, Jam. 10.30, Tanggal 12 April 2018
} 
Pemerintahan Kabupaten memberikan dana sebesar 50 juta di tahap pertama kepada Lembaga BUMDESA dan memberikan nya kepada masyarakat sesuai dengan kesepatakan penggurus BUMDESA dan aparat desa kepada masyarakat dengan aturan-aturan tertentu, selanjutnya pada tahap kedua pemerintahan kabupaten memberikan dana sebesar 100 juta kepada BUMDESA untuk dapat lebih memberikan bantuan kepada masyarakat desa Liberia agar masyarakat tersebut dapat lebih memajukan perekonomian mereka yang telah di jalani. $^{26}$

Table 1. Jumlah peminjam masyarakat desa Liberia kecamatan teluk mengkudu kabupaten serdang bedagai kepada Badan Usaha Milik Desa (BUMDESA) BUMDESA.

\begin{tabular}{|l|c|c|c|c|c|c|}
\hline \multirow{2}{*}{ No } & \multicolumn{3}{|c|}{ Jumlah Peminjam Dusun } & \multicolumn{3}{c|}{ Dana Pencairan Pinjaman } \\
\cline { 2 - 7 } & I & II & III & I & II & III \\
\hline 1 & 41 Anggota & 59 Anggota & 43 Anggota & 30 Juta & 40 Juta & 30 \\
& & & & & & Juta \\
\hline
\end{tabular}

Sumber : Data Wawancara Dengan Bendahara BUMDESA Di Desa Liberia Kecamatan

Teluk Mengkudu Kabupaten Serdang Bedagai April 2018

Sebagian besar masyarakat desa liberia kecamatan teluk mengkudu kabupaten serdang bedagai melakukan simpan pinjam yang telah di gerakkan dan dijalankan oleh BUMDESA serta di kelola bersama dengan masyarakat. Adapun jumlah peminjaman dari setiap dusun sebelum nya mereka melakukan pelatihan dan arahan dari BUMDESA agar penggolahan dana simpan pinjam yang diberikan oleh BUMDESA berhasil serta tidak mengalami hal yang tidak mereka inginkan diantara nya keberhasilan dalam berusaha dan dapat memajukan usaha mereka dari memanfaatkan hasil pinjaman dari BUMDESA. ${ }^{27}$ Desa leberia mempunyai 3 (Tiga) dusun yang masih aktif menjalankan kegiatan BUMDESA dalam simpan pinjam. Setiap peminjam dari BUMDESA mereka dapat membayar dengan cara menganggsur pada setiap bulan nya dengan persenan yang kecil yaitu $1 \%$ dalam jangka 1 tahun dari dana yang telah di pinjam kepada BUMDESA . Persenan tersebut digunakan untuk dana keuntungan jasa dan PAD yang dikembalikan ke unit usaha keuangan BUMDESA agar tidak mengalami kerugian

\footnotetext{
${ }^{26}$ Ibid, Jam 10. 30, Tanggal 12 April 2018

${ }^{27}$ Ibid, Jam 10. 35 Wib, Tanggal 12 April 2018
} 
hal ini dapat menutupi jika anggota tidak bisa membayar pada waktu yang telah di tetapkan. ${ }^{28}$

\section{Unit Jasa dan PAD}

Unit usaha jasa yang telah didirikan oleh BUMDESA ialah unit usaha simpan pinjam. Berdasarkan hasil interview, bentuk simpanan yang ada yaitu tabungan masyarakat desa Liberia serta tabungan usaha mikro desa Liberia. Unit usaha simpan pinjam ini diadakan dengan tujuan untuk memberikan dukungan kepada masyarakat dalam meningkatkan usahanya agar tidak kehabisan modal, serta membantu masyarakat untuk menabung pada kebutuhan mendatang, seperti kebutuhan sekolah dan keseharian. Hal tersebut di kelola oleh BUMDESA dengan cara memutarkan kembali kepada masyarakat yang membutuhkan simpan pinjam tersebut. Dengan adanya kegiatan ini dapat membantu masyarakat dari kesulitan mendapatkan modal usaha. ${ }^{29}$

Hal di atas juga di tegaskan oleh penduduk desa Liberia kecamatan teluk mengkudu kabupaten serdang bedagai bahwa melalui simpan pinjam melalui BUMDESA masyarakat tidak kesulitan mencari modal lagi selain masyarakat tersebut bisa menambah modal mereka juga bisa menabung, sehingga usahanya bisa di control dengan baik pemasukkannya. Berdasarkan hasil interview dan observasi juga, masyarakat banyak tertarik dengan jasa simpan pinjam ini selain membantu masyarakat BUMDESA mampu membantu masyarakat untuk memiliki tekad memulai usaha. ${ }^{30}$

3. Kegiatan Badan Usaha Milik desa BUMDESA dalam memberdayakan masyarakat desa

Usaha-usaha dalam pendapatan ekonomi masyarakat desa Liberia melalui BUMDESA dilakukan melalui beberapa kegiatan diantaranya adalah sebuah upaya melakukan pemberdayaan masyarakat. Pelatihan-pelatihan sebagai penunjang untuk meningkatkan kualitas sumber daya manusia didesa Liberia yang mandiri., kreatif, kompotitif, serta memiliki etos kerja yang tinggi. Usaha peningkatan pendapatan ekonomi masyarakat tujuannya adalah untuk meningkatkan kesajateraan masyarakat serta membantu mengembangkan kegiatan

\footnotetext{
${ }^{28}$ Ibid, Jam 10. $40 \mathrm{Wib}$, Tanggal 12 April 2018

${ }^{29}$ Ibid, Jam 10.40 Wib, Tanggal 12 April 2018

${ }^{30}$ Ibid, Jam 11. $00 \mathrm{Wib}$, Tanggal 12 April 2018
} 
usaha masyarakat. Beberapa usaha pengembangan ekonomi masyarakat yang dilakukan melalui program BUMDESA, yaitu : ${ }^{31}$

a. Penyuluhan

Kegiatan penyuluhan dilakukan oleh penggurus BUMDESA adalah untuk memberikan informasi mengenai berdirinya BUMDESA. Kegiatan penyuluhan ini juga dilakukan dalam bentuk sosialisasi unit usaha yang di jalankan oleh desa Liberia melalui BUMDESA kepada masyarakat, agar mayarakat ikut serta merealisasikan unit usaha tersebut. ${ }^{32}$

Bapak Dirga Wira Setia sekalu Direktur BUMDESA menyatakan bahwa penyuluhan ini dilakukan agar unit usaha simpan pinjam yang di bentuk sesuai kebutuhan masyarakat yang bisa membantu mengembangkan ekonomi masyarakat desa tersebut. Maka perlu kepenggurusan BUMDESA ini masyarakat desa Liberia itu sendiri sehingga mudah memberikan pemahaman kepada masyarakat bahwa BUMDESA ikut andil dalam memajukan perekonomian masyarakat walaupun bantuan yang diberikan BUMDESA tidak terlalu besar hanya saja bisa memberikan kemudahan kepada masyarakat desa Liberia. ${ }^{33}$

b. Pelatihan kewirausahaan

Pelatihan kewirausahaan dilakukan sebagai bentuk upaya meningkatkan kualitas sumber daya manusia masyarakat desa Liberia. Kegiatan pelatihan ini guna untuk memberikan memberikan pemahaman kepada masyarakat bahwa kegiatan kewirausahaan mampu meningkatkan perekonomian masyarakat. Ibu Evi Herawati selaku bendahara BUMDESA mengatakan walaupun pelatihan kewirausahan ini berjalan hanya pada kegiatan simpan pinjam bukan berarti tidak memberikan wawasan kepada masyarakat desa Liberia agar masyarakat lebih berkreatif dalam mengembangkan usaha yang mereka jalani serta dapat mengelola uang yang mereka pinjam kepada BUMDESA sehingga tidak habis begitu saja, artinya dari dana pinjaman sebesar 3-5 juta perorang yang mendapatkan dana cair dari BUMDESA harus memanfaatkan dan harus dikelola sebaik mungkin agar tidak habis begitu saja dan tidak dapat apa-apa. Pelatihan ini untuk mengingatkan

\footnotetext{
${ }^{31}$ Ibid, Jam 11.00 Wib, Tanggal 12 April 2018

${ }^{32}$ Ibid, Jam 11.00 Wib, Tanggal 12 April 2018

${ }^{33}$ Wawancara Dengan Bapak Dirga Wira Setia, Direktur BUMDESA, Aula Kantor Desa Liberia Kecamatan Teluk Mengkudu Kabupaten Serdang Bedagai, Jam 10.00, Tanggal 16 April 2018.
} 
serta memberikan arahan kepada masyarakat harus mampu meningkatkan perekonomian usahanya, walaupun BUMDESA desa Liberia pada saat ini berperan pada unit usaha simpan pinjam. ${ }^{34}$

Selain program unit usaha simpan pinjam yang dilakukan oleh BUMDESA masyarakat dilatih pada perternakan bebek yang di gerakkan oleh BUMDESA yang baru berjalan kurang lebih sekitar 6 bulan, hal ini untuk membantu masyarakat dalam memanfaatkan telur dan hasil dari ternaakan bebek tersebut. ${ }^{35}$

Pertenakan ini tidak terlalu banyak hanya sekitar 60 ekor bebek dan diberikan kepada setiap dusun secara bertahap, masing-masing setiap dusun bergantian mendapatkan perternakan bebek ini dikarenakan jumlah yang tidak terlalu banyak untuk dapat di kelola. selanjutnya bebek ini dikelola maupun dipelihara oleh penduduk dusun II desa liberia dan di ternakan menjadi satu kandang sehingga dengan begitu lebih mudah memperhatikan perkembangan ternakan bebek tersebut dan dengan mudah mengetahui gejala apa yang menghambat perkembangan pertenakan bebek tersebut, dengan begitu pertenakan ini akan bisa lebih berlanjut dan berhasil. ${ }^{36}$

Hasil dari pelatihan perternakan bebek yang digerakkan oleh BUMDESA ini dapat memberikan kemudahan kepada masyarakat dalam meningkatkan usaha dan perekonomiannya dengan menjual telur bebek ke warung-warung dan grosiran sehingga desa mendapatkan hasil yang bagi rata atas penjualannya. Ternakan bebek yang dapat menghasilkan telur belum dapat terlalu dikembangkan maupun di manfaatkan dalam kondisi tersebut dikarenakan perternakan bebek ini baru berjalan kurang lebih dari 6 bulan dan hasil nya juga tidak sesuai dengan pengeluaran dana makan bebek, jika masyarakat mempunyai makanan sisa dan lebih maka bisa dimanfaatkan untuk makanan perharinya namun hal ini jarang hanya sesekali saja, masyarakat membeli dedak untuk makanan perharinya, sekilo dengan harga 2000 sebanyak 50 kilo yang harus dipenuhi dalam setiap bulannya, maka dana yang habis untuk biaya makan bebek sekitar 100 ribu rupiah dalam

\footnotetext{
${ }^{34}$ Wawancara Kepada Ibu evi Herawati, Bendahara BUMDESA, Kantor Desa, Desa Liberia Kecamatan Teluk Mengkudu Kabupaten Serdang Bedagai, Jam 10. 50, Tanggal 17 April 2018

${ }^{35}$ Ibid, Jam 10.00 Wib, Tanggal 16 April 2018

${ }^{36}$ Ibid, Jam 10.50, Tanggal 17 April 2018
} 
setiap 40 harinya, agar untuk menghasilkan telur bebek tersebut harus menunggu selama kurang lebih dua bulan dan setiap harinya telur menghasilkan 30 butir telur. $^{37}$

Hal ini tergantung kepada faktor lingkungan atau pun pemeliharaannya karena hal ini mempengaruhi produktifitas bebek diantaranya adalah kesehatan bebek, mutu dan kestabilan makan, kondisi kandang, suhu, iklim dan stres. Dengan sifat bebek sebagai binatang yang anti perubahan, maka bila salah satu faktor tersebut terganggu maka produktifitas telur akan terganggu atau bahkan bisa berhenti sama sekali. Dengan kata lain faktor lingkungan sangat berperan dalam panjang/lamanya produktivitas bebek bertelur. Bila bebek sakit, kandang becek dan bau, hujan lebat/banjir ataupun stress akan mengurangi jumlah telur yang dihasilkan dari yang semestinya. ${ }^{38}$

c. Peminjam modal

Cara pengembangan usaha dan pengelolaan dana pinjam untuk masyarakat yang dilakukan oleh BUMDESA adalah dana dari desa yang merupakan hasil dana terkumpul dari setiap unit usaha yang dibuka oleh BUMDESA. Masyarakat diberi pinjaman sesuai dengan bentuk usaha yang dimilikinya. ${ }^{39}$

\section{Hambatan BUMDESA Dalam Memberdayakan Masyarakat Desa di Desa}

\section{Liberia}

Badan Usaha Milik Desa (BUMDESA) belum dapat dijalankan seperti pada maksud pendirian dan tujuannya. Hal ini tersebut terjadi karena masih banyaknya kendala yang terjadi dalam lembaga tersebut seperti : ${ }^{40}$

a. Kurangnya modal yang dimiliki oleh BUMDESA.

b. Kurangnya keterampilan dan kecakapan sumber daya manusia dalam kepenggurusan BUMDESA.

c. Manajemen kelembagaan yang masih sangat kurang berjalan dengan baik seperti perencanaan dalam menjalankan usaha untuk memperoleh keuntungan dan manfaat dengan maksimal.

\footnotetext{
${ }^{37}$ Ibid, Jam 10.00 Wib, Tanggal 16 April 2018

${ }^{38}$ Ibid, Jam 10.00 Wib, Tanggal 16 April 2018

${ }^{39}$ Ibid, Jam $10.00 \mathrm{Wib}$, Tanggal 16 April 2018

${ }^{40}$ Ibid, Jam 10.10 Wib, Tanggal 16 April 2018
} 
d. Faktor lain adalah kurangnya pengetahuan masyarakat tentang BUMDESA dan masih minimnya partisifasi masyarakat dalam memajukan unit usaha yang dikelola masyarakat.

Banyak kebijakan pemerintah yang berorientasi kepada masyarakat kecil yang bertujuan untuk meningkatkan kesejaheraan masyarakat. Namun kebijakankebijakan yang sudah di rasa belum optimal dampaknya kepada masyarakat kecil. Oleh karena itu pemerintah membuat kebijakan berbentuk lembaga ekonomi di tingkat pedesaan. Organisasi ekonomi ditingkat pedesaan menjadi bagian yang sangat penting dalam rangka untuk mendukung pemberdayaan dan penguatan ekonomi karakyatan. Karena sebagian besar di desa terdapat anggota masyarakat yang tercatat sebagai usaha ataupun pedagang. ${ }^{41}$

Berikut adalah laporan hasil penelitian pada BUMDESA di desa Liberia yang dilakukan oleh peneliti dengan mewawancarai 5 responen yang terdiri dari pengurus BUMDESA, kepala desa, dan masyarakat yang melakukan unit usaha simpan pinjam melalui BUMDESA, guna untuk mengetahui perkembangan BUMDESA yang ada di desa Liberia tersebut.

\section{Keberhasilan Yang Dicapai Oleh BUMDESA Dalam Memberdayakan Masyarakat Desa Liberia}

Dengan adaya unit usaha simpan pinjam telah memberikan wawasan kepada masyarakat serta mendorong tumbuhnya perekonomian masyarakat desa sehingga lebih memajukan usaha dari permodalan melalui BUMDESA. Menciptakan lapangan kerja hal ini dimanfaatkan masyarakat melalui BUMDESA untuk lebih memanfaatkan potensi desa dengan permodalan unit usaha sim pan pinjam yang telah di jalankan oleh pemerintah desa Liberia. ${ }^{42}$

Dengan hal ini lebih membantu perekonomian masyarakat dalam meningkatkan usaha serta meringankan masyarakat dalam pengembalian dana dengan cicilan perbulan dengan jumlah persenan hanya $1 \%$ dari dana pinjaman tersebut dalam jangka satu tahun, $1 \%$ keuntungan itu pula digunakan untuk unit jasa dan pendapatan asli desa (PAD). Sehingga dana tersebut tetap bisa digunakan untuk kegiatan yang akan diperlukan oleh pemerintah desa dalam memberdayakan

${ }^{41}$ Ibid, Jam $10.50 \mathrm{Wib}$, Tanggal 17 April 2018

${ }^{42}$ Ibid, Jam 10. 10 Wib, Tanggal 16 April 2018 
masyarakat dengan begitu perkembangan BUMDESA akan lebih meningkat dan tidak mengalami kerugian dalam permodalan. ${ }^{43}$

Dari hasil wawancara yang peneliti/penulis lakukan secara langsung pada hari Selasa, 17 April 2018, Hal ini diharapkan harus adanya koordinasi yang baik antar pengurus BUMDESA dan pemerintah desa serta masyarakat untuk keberlangsungan BUMDESA dalam memiliki strategi untuk menarik minat masyarakat agar bersama-sama dapat mengelola potensi yang dimiliki desa Liberia sehingga dapat meningkatkan taraf hidup masyarakat sehingga dapat memberdayakan masyarakat. ${ }^{44}$

Badan usaha milik desa atau yang disebut BUMDESA didesa liberia kecamatan teluk mengkudu kebupaten serdang bedagai adalah badan usaha milik desa berdiri pada tanggal 18 April 2016 dengan Surat keputusan (SK) kepala desa nomor 02/2016 tentang BUMDESA serta di lengkapi anggaran dasar dan anggaran rumah tangga yang sesuai dengan peraturan perundang undangan dari tahun 2016-2018 BUMDESA telah berjalan selama kurang lebih 3 tahun. Badan usaha milik desa ini berdiri di karenakan pemerintah desa ingin membentuk sebuah lembaga perekonomian yang dapat mengelola potensi yang di miliki oleh desa Liberia.selain untuk mengelola potensi desa yang dimiliki juga sebagai sarana dalam memberdayakan masyarakat desa Liberia. Banyak potensi desa yang dapat dikekola yang menjadi sumber pendapatan bagi masyarakat oleh karna itu pemerintah desa mendirikan BUMDESA ini untuk membantu masyarakat dalam mengelola potensi-potensi tersebut. ${ }^{45}$

Potensi desa yang ada di desa Liberia adalah potensi pertanian perkebunan kelapa sawit, singkong, coklat, jagung milik masyarakat. Secara umum potensi andalan di desa Liberia adalah pada sektor perkebunan.selanjutnya melihat dari potensi-potensi desa maka BUMDESA mendirikan unit usaha yang bergerak dibidang simpan pinjam modal. Modal yang dimiliki BUMDESA berasal dari pemerintah desa yang berupa dana atas kesepakatan bersama untuk modal usaha yang dijalankan oleh masyarakat dalam meningkatkan perekonomian desa. ${ }^{46}$

\footnotetext{
${ }^{43}$ Ibid, Jam 11.00 Wib, Tanggal 17 April 2018

${ }^{44}$ Ibid, Jam 10.10 Wib, Tanggal 17 April 2018

${ }^{45} \mathrm{Ibid}$, Jam 14.10 Wib, Tanggal 17 April 2018

${ }^{46}$ Ibid, Jam 11.00 Wib, Tanggal 17 April 2018
} 
d. Partisipasi masyarakat dalam proses pengembangan ekonomi

Indikator keberhasilan BUMDESA dalam mengembangkan ekonomi masyarakat yang dimulai sejak tahun 2016 adalah partisifasi masyarakat itu sendiri. Masyarakat adalah aktor utama dalam meningkatkan menjadi modal utama dalam memberdayakan masyarakat dan mendorong kemandirian desa. Maka dari itu, partisipasi masyarakat dalam proses pengembangan ekonomi masyarakat melalui BUMDESA meliputi $:^{47}$

\section{a. Perencanaan}

Partisipasi masyarakat dalam perencanaan dimulai pada tahap keikutsertaan masyarakat dalam membentk BUMDESA sebagai badan otonomi desa yang memiliki wewenang memobilisasi kagiatan usaha masyarakat. Partisipasi masyarakat selanjutnya dalam perencanaan adalah kehadiran masyarakat dalam sosialisasi dan perencanaan kegiatan BUMDESA, berdasarkan hasil observasi 18 April 2016, masyarakat mendukung dan merespon dengan baik berdirinya BUMDESA. Seperti yang dikatakan Ibu Nurhasanah selaku anggota simpan pinjam BUMDESA menurutnya dalam proses pendirian dan perencanaan kegiatan BUMDESA masyarakat dilibatkan untuk ikut serta dalam rapat pembentukan yang dilakukan dibalai desa. ${ }^{48}$

Dalam sosialisasi untuk perencanaan unit usaha yang akan dikelola BUMDESA masyarakat dilibatkan baik ibu-ibu maupun bapak-bapak yang memang mereka memiliki peran dalam kegiatan usaha simpan pinjam tersebut. Peryataan ini juga di perjelas oleh Ibu Ade Septia Ningsih selaku sekretaris BUMDESA bahwa BUMDESA untuk membantu masyarakat dalam mengembangkan usahanya, kalau masyarakat kurang peduli tidak akan terlaksana. $^{49}$

Pada awal pembentukan masyarakat sangat antusias mendukung sekali, sampai sekarang juga sangat mendukung namun terkadang masih ada sebagaian masyarakat terdapat partisipasinya yang kurang akan BUMDESA ini. Padahal

${ }^{47}$ Ibid, Jam 14.10 Wib, Tanggal 17 April 2018

${ }^{48}$ Wawancara kepada Ibu Nurhasanah, Peminjam Unit Usaha Simpan Pinjam BUMDESA, Rumah Penduduk, Desa Liberia Kecamatan Teluk Mengkudu Kabupaten Serdang Bedagai, Jam 15.05 Wib, Tanggal 18 April 2018.

${ }^{49}$ Wawancara Kepada Ibu Ade Septia Ningsih, Sekretaris BUMDESA, Kantor Desa, Desa Liberia Kecamatan Teluk Mengkudu Kabupaten Serdang Bedagai, Jam 09.50 Wib, Tanggal 18 April 2018 
unit usaha yang dikelola dengan baik oleh BUMDESA itu juga merupakan hasil musyawarah bersama masyarakat, karena memang dengan adanya pasar kegiatan usaha simpan pinjam kepada masyarakat untuk menumbuhan perekonomian yang baik dengan itu perlu pandangan yang lebih serius agar kegiatan simpan pinjam ini dapat terlaksana dan bermanfaat dengan sebaik mungkin kepada masyarakat didesa Liberia kecamatan teluk mengkudu kabupaten serdang bedagai. ${ }^{50}$

Namun dari sisi lain dari hasil observasi dan interview, penulis menemukan perbedaan pendapat dari beberapa masyarakat yang tinggal di sekitar dusun III dimana masyarakat kurang paham mengetahui keberadaan BUMDESA itu sendiri. Menurutnya mungkin dikarenakan kurang komunikasi kepala desa dengan masyarakat tersebut dikarenakan jarak tempuh kantor desa dengan beberapa rumah penduduk yang berada di pendalaman. ${ }^{51}$

\section{b. Pelaksanaan}

Partisipasi masyarakat didalam pelaksanaan dilakukan setelah dilakukannya perencanaan. Bentuk partisipasi masyarakat dalam pengelolaan unit usaha yang dilakukan oleh BUMDESA seperti masyarakat yang telah melakukan simpan pinjam kepada BUMDESA sudah termasuk partisipasi membantu merealisasikan BUMDESA. Pelaksanaan ini dilakukan setelah selesai perencanaan dan kegiatan pelatihan kewirausahaan yang dilakukan oleh BUMDESA yang tujuannya adalah untuk memberdayakan masyarakat setempat. ${ }^{52}$

Selanjutnya Setelah masyarakat mempunyai skil dalam mengembangakan usahanya dari unit simpan pinjam yang telah dilakukan oleh BUMDESA, BUMDESA berharap masyarakat dapat percaya kepada BUMDESA untuk mengembangkan usaha demi manfaat bersama. Simpan pinjam ini juga telah terlaksana pada setiap dusun yang ada didesa tersebut dan penggurus BUMDESA memberikan pengarahan agar masyarakat itu lebih memanfaatkan modal yang telah ada agar pemasukkan masyarakat juga bertambah dengan adanya pelaksanaan dan penggarahan dapat memberikan masukkan kepada masyarakat dan tidak mengharapkan bantuan dana dari atas saja. Hal ini dilakukan setelah

\footnotetext{
${ }^{50}$ Ibid, Jam 09.50 Wib, Tanggal 18 April 2018

${ }^{51}$ Ibid, Jam 09.55 Wib, Tanggal 18 April 2018

${ }^{52}$ Ibid, Jam 09.55 Wib, Tanggal 18 April 2018
} 
masyarakat tersebut mengembalikan dana pinjamannya kepada BUMDESA yang hampir akan lunas hal ini membantu BUMDESA dalam mengundang fartisifasi masyarakat. $^{53}$

\section{c. Permodalan}

Permodalan dilakukan sebagai upaya membantu masyarakat yang memiliki usaha kecil menegah. Dengan adanya unit usaha simpan pinjam masyarakat juga bisa menjadi modal membantu masyarakat mengembangkan usahanya. BUMDESA harus menyisihkan secara Khusus dana yang terkumpul untuk kegiatan pemberdayaan masyarakat, karena kalau sudah masuk dalam keuangan desa, dana tersebut pasti digunakan untuk kebutuhan fisik desa, dan masyarakat kembali tidak diperhatikan kegiatan usahanya. ${ }^{54}$

Permodalan yang dilakukan BUMDESA harus dimonitoring kembali agar masyarakat yang membutuhkan permodalan dalam mengembangkan usaha bisa terbantu, sehingga BUMDES berjalan dengan baik dan tidak akan mati. ${ }^{55}$

d. Monitoring dan evaluasi

Monitoring dan evaluasi dibutuhkan dalam kegiatan BUMDESA agar semua unit usaha yang dibentuk BUMDESA berjalan dengan baik dan sesuai dengan yang telah direncanakan sebelumnya merupakan tugas dan kewajiban pengurus dan anggota BUMDESA serta pemerintah desa setempat. Kalau tidak ada kegiatan ini, unit usaha yang dijalankan atau yang didirikan akan berhenti dan bisa merugikan seluruh lapisan masyarakat. ${ }^{56}$

Selain itu juga, peran masyarakat dalam kegiatan monitoring dan evaluasi sangat penting. Tahap ini masyarakat ikut dilibatkan guna mengawasi berjalannya setiap unit usaha yang dilakukan oleh BUMDESA agar sesuai dengan kebutuhan masyarakat. Hal ini dijelaskan oleh penggurus BUMDESA bapak Dirga Wira setia bahwa masyarakat memang benar harus dilibatkan dalam mengawasi segala kegiatan desa. Apalagi saat ini, dana desa sangat tinggi kalau masyarakat tidak

\footnotetext{
${ }^{53}$ Ibid, Jam 09.50 Wib, Tanggal 18 April 2018

${ }^{54}$ Ibid, Jam 10.00 Wib, Tanggal 16 April 2018

${ }^{55}$ Ibid, Jam 10.00 Wib, Tanggal 16 April 2018

${ }^{56}$ Ibid, Jam 10.10 Wib, Tanggal 16 April 2018
} 
mengawasi dengan baik, takutnya ada penyimpangan yang dilakukan aparat desa. $^{57}$

Bentuk partisipasi masyarakat dalam mengawasi adalah melaporkan setiap gerak pengurus BUMDESA dan aparat desa yang kurang baik misalnya dalam rapat desa, mengamati perkembangan pembangunan desa dan sebagainya. Namun hal tersebut masyarakat kurang peduli, sehingga masyarakat kalau ada kesalahan didesa hanya bisa berbicara diluar. ${ }^{58}$

Berdasarkan hasil koesioner tentang kondisi sosial responden setelah adanya unit usaha BUMDESA diperoleh kesimpulan yaitu, bahwa tingkat sosial keluarga masyarakat desa Liberia belum meningkat walaupun adanya BUMDESA ini dikarenakan belum adanya modal usaha bagi sebagian besar masyarakat juga membuat kurang dikenalnya lembaga perekonomian ini. Tetapi sebagian besar masyarakat menyatakan dampak adanya keberadaan unit usaha yang dikelola BUMDESA berdampak positi terutama bagi para petani dan pedagang kecil dengan adanya unit usaha simpan pinjam dari BUMDESA dengan persenan yang sangat kecil sehingga masyarakat termudahkan dengan tambahan modal yang telah dijalankan. ${ }^{59}$

Walaupun dari kondisi ekonomi dan kondisi sosial yang menjadi indikator dari badan usaha milik desa (BUMDESA) sampai saat ini belum bisa dikatakan meningkat, karena masih banyak masyarakat yang belum mengetahui apa itu BUMDESA walaupun mereka telah menggunakan unit usaha yang ada tetapi partisifasi masyarakat untuk ikut berpartisifasi langsung dalam menggali potensi desa yang dimiliki masih sangat kurang. ${ }^{60}$

Wawancara dengan Ibu Nurhasanah pada tanggal 18 April 2018 mengatakan bahwa Bukan hanya dari masyarakat yang menjadi kendala bagi kemajuan BUMDESA ini penggurus serta pemerintah juga menjadi salah satu kendala. Sumber daya manusia atau penggurus yang ada belum mampu membuat lembaga perekonomian ini dengan baik. Faktor lain dari segi kepenggurusan yaitu kurang matangnya sumber daya manajemen yang dimiliki oleh BUMDESA,

\footnotetext{
${ }^{57}$ Wawancara Dengan Bapak Dirga Wira setia, Direktur BUMDESA, Jam 14.00 Wib, Tanggal 19 April 2018

${ }^{58}$ Ibid, Jam 14.00 Wib, Tanggal 19 April 2018

${ }^{59}$ Ibid, Jam 14.00 Wib, Tanggal 19 April 2018

${ }^{60}$ Ibid, Jam 14.00 Wib, Tanggal 19 April 2018
} 
kurangnya pengawasan dan peninjauan juga berpengaruh. Selain itu kurangnya dukungan modal dari pemerintah pusat juga menyulitkan BUMDESA ini untuk berkembang dan berperan dalam memberdayakan masyarakat. ${ }^{61}$

\section{PENUTUP}

Berdasarkan hasil penelitian yang dikemukan di atas, skripsi ini membahas tentang peran badan usaha milik desa (BUMDESA) dalam memberdayakan masyarakat desa Liberia dalam meningkatkan ekonomi melalui unit usaha simpan pinjam, maka permasalahan ini yang ada dan dapat di tarik kesimpulan sebagai berikut :

1. Peran BUMDESA terhadap memberdayakan masyarakat dalam meningkatkan ekonomi dan unit usaha yang dimiliki oleh karena itu perlulah koordinasi yang baik antar penggurus BUMDESA dan pemerintah desa serta masyarakat untuk keberlangsungan BUMDESA sehingga dapat memberdayakan masyarakat desa. Penggurus BUMDESA juga harus memiliki strategi untuk menarik minat masyarakat agar bersama-sama dapat mengelola potensi yang dimiliki desa Liberia sehingga dapat meningkatkan taraf hidup masyarakat serta dapat memberdayakan masyarakat.

2. Perkembengan ekonomi dilihat dari beberapa indikator pemperdayaan masyarakat di desa Liberia dari tingkat pendapatan masyarakat, pengeluaran masyarakat, tingkat pendidikan masyarakat dan tingkat penggelolahan BUMDESA desa ini sudah dapat dikatakan masyarakat yang sudah dapat keadilan dan kepedulian dari pemerintahan desa dan telah berhasil memanfaatkan modal dari BUMDESA.

3. Faktor penghambat dan pendukung dari BUMDESA dalam meberdayakan masyarakat desa kurang nya fartisifasi masyarakat dan kurangnya modal dari BUMDESA hal ini membuat masyarakat hanya bergiliran menerima modal dari BUMDESA. Dan faktor pendukungnya BUMDESA mampu memberikan wawasan kepada masyarakat sehingga menumbuhkan perkembangan perekonomian

\footnotetext{
${ }^{61}$ Ibid, Jam 15. 05 Wib, Tanggal 18 April 2018
} 
agar tidak mengalami kerugian dari permodalan yang telah di berikan oleh BUMDESA hal ini pula tidak memberatkan masyarakat simpan pinjam ini di bayar dengan cicilan persenan yang sangat rendah dan persenan tersebut kembali kepada kas desa.

\section{DAFTAR PUSTAKA}

Boediono.1993.Teori Pertumbuhan Ekonomi.Yogyakarta: BPFE

Surjadi.1989. Pembangunan Masyarakat Desa,Bandung : Mandar Maju

Yustisida Tim Visi. 2016. Pedoman Resmi Petunjuk Pelaksanaan Dana Desa. Jakarta: PT. Visimedia Pustaka Anggota IKAPI.

Robert. Chamber,1987. Pembangunan Desa, Jakarta: LP3ES

Moedzair Dgauzi.1986. Teori dan Praktek Pengembangan Masyarakat. Surabaya Usaha Nasional

Suharsono Edy.2016. Teori Peran konsep, derivasi, dan implikasinya. Jakarta: PT Gramedia Pustaka Utama

Fahrudin Adi. 2012. Pengantar Kesejahteraan Sosial. Bandung: PT Refika Aditama.

Soekanto Soejono. 1990. Sosiologi Suatu Pengantar. Jakarta: PT Raja Grafindo Persada

Suit Jusuf. 2012. Pemberdayaan Potensi Ekonomi Pedesaan, Jakarta: IPB Pres

Zubaedi. 2013. Pengembangan masyarakat wacana \& praktis. Jakarta: Kencana Prenada Media Group

Anwas. Oos M. 2014. Pemberdayaan Masyarakat Di Era Global. Bandung.

\section{ALFABETA}

Randy R. Wrihatnolo Riant Nugroho Dwidjowijoto. 2010. Manajemen Pemberdayaan. Jakarta: PT. Elex Media Komputindo

Mikkelsen Britha. 2012. Metode Penelitian Partisipatoris dan upaya pemberdayaan. Jakarta: Yayasan Pustaka Obor Indonesia

Surakhmad Winarno. 1982. Pengantar Penelitian Ilmiah. Bandung: Tarsino.

Noor Juliansyah. 2011. Metodelogi Penelitian. Jakarta: Kencana Prenadamedia Group

Bungin Burhan. 2011. Metodologi Penelitian Kualitatif. Jakarta: Raja Wali Pers 
JURNAL PEMBERDAYAAN MASYARAKAT 218

Volume 6 No. 2 Tahun 2018 ISSN: 2355-8679

Sugiono. 2008. Metode Penelitian Kuantitatif dan Kualitatif. Bandung; Alfabeta. 